\title{
Melipona mondury produces a geopropolis with antioxidant, antibacterial and antiproliferative activities
}

\author{
TÁSSIA L.A. DOS SANTOS ${ }^{1}$, RAPHAEL F. QUEIROZ ${ }^{2}$, ALEXANDRA C.H.F. SAWAYA ${ }^{3}$, BEGOÑA \\ GIMENEZ-CASSINA LOPEZ ${ }^{3}$, MILENA B.P. SOARES ${ }^{4,5}$, DANIEL P. BEZERRA ${ }^{4}$, ANA CAROLINA \\ B.C. RODRIGUES ${ }^{4}$, VANDERLÚCIA F. DE PAULA ${ }^{6}$ and ANA MARIA WALDSCHMIDT ${ }^{1}$
}

\author{
${ }^{1}$ Departamento de Ciências Biológicas, Universidade Estadual do Sudoeste da Bahia, Rua \\ José Moreira Sobrinho, s/n, Jequiezinho, 45208-091 Jequié, BA, Brazil \\ ${ }^{2}$ Departamento de Ciências Naturais, Universidade Estadual do Sudoeste da Bahia, Estrada \\ do Bem Querer, Km 04, s/n, 45031-900 Vitória da Conquista, BA, Brazil \\ ${ }^{3}$ Departamento de Biologia e Ciências Farmacêuticas, Instituto de Biologia, Universidade Estadual de \\ Campinas, Rua Monteiro Lobato, 255, Cidade Universitária, 13083-862 Campinas, SP, Brazil \\ ${ }^{4}$ Instituto Gonçalo Moniz, Fundação Oswaldo Cruz/IGM-FIOCRUZ-BA, Rua \\ Waldemar Falcão, 121, Candeal, 40296-710 Salvador, BA, Brazil \\ ${ }^{5}$ Centro de Biotecnologia e Terapia Celular, Hospital São Rafael, Avenida São \\ Rafael, 2152, São Marcos, 41253-190 Salvador, BA, Brazil \\ ${ }^{6}$ Departmento de Química e Ciências Exatas, Universidade Estadual do Sudoeste da Bahia, \\ Rua José Moreira Sobrinho, s/n, Jequiezinho, 45208-091 Jequié, BA, Brazil
}

Manuscript received on October 26, 2016; accepted for publication on March 3, 2017

\begin{abstract}
Geopropolis is a special type of propolis produced by stingless bees. Several pharmacological properties have been described for different types of geopropolis, but there have been no previous studies of the geopropolis from Melipona mondury. In this study, we investigated the antioxidant, antibacterial, and antiproliferative activities of $M$. mondury geopropolis, and determined its chemical profile. The antioxidant activity was determined using in vitro $\mathrm{ABTS}^{\bullet}{ }^{\bullet}$, $\mathrm{DPPH}$, and $\beta$-carotene/linoleic acid co-oxidation methods. The antibacterial activity was determined using a microdilution method with Pseudomonas aeruginosa, Staphylococcus aureus, and methicillin-resistant $S$. aureus. The antiproliferative effect was determined in tumor cell lines using the Alamar Blue assay. The chemical profile was obtained using UHPLC-MS and UHPLC-MS/MS. The butanolic fraction had the highest concentration of phenolic compounds and more potent antioxidant properties in all assays. This fraction also had bacteriostatic and bactericidal effects against all bacterial strains at low concentrations, especially $S$. aureus. The hexane fraction had the highest antiproliferative potential, with $\mathrm{IC}_{50}$ values ranging from 24.2 to $46.6 \mu \mathrm{g} / \mathrm{mL}$ in HL-60 (human promyelocytic leukemia cell) and K562 (human chronic myelocytic leukemia cell), respectively. Preliminary chemical analysis indicates the presence of terpenes and gallic acid in the geopropolis. Our results indicate the therapeutic potential of geopropolis from M. mondury against inflammatory, oxidative, infectious, and neoplastic diseases.
\end{abstract}

Key words: antibacterial, antioxidant, antiproliferative, geopropolis, Melipona mondury.

\footnotetext{
Correspondence to: Raphael Ferreira Queiroz

E-mail: rfqueiroz@uesb.edu.br

Ana Maria Waldschmidt

E-mail: amwalds@gmail.com
} 


\section{INTRODUCTION}

Geopropolis is a mixture of resin, wax, and soil, and it is an uncommon type of propolis produced by native stingless bees from the Meliponini tribe, which are widely distributed in tropical and subtropical areas worldwide (Sforcin and Bankova 2011, Souza et al. 2014). The geopropolis from Melipona mondury (Hymenoptera: Apidae: Meliponini) was investigated in the present study because this bee species is distributed extensively in Brazil, especially in Bahia state in the northeast of the country (Melo 2003). M. mondury is found exclusively in warm and humid climates in about $24 \%$ of the municipalities of Bahia state (Souza et al. 2012). In addition to their importance as efficient pollinators of native flora, stingless bees yields products such as honey, pollen, and geopropolis, which are sources of food, medicine, and income for the rural population (Melo 2003).

Studies of different types of geopropolis have demonstrated their significant antinociceptive (Souza et al. 2014), anti-inflammatory (Franchin et al. 2013, Campos et al. 2015), antioxidant (Souza et al. 2014, Campos et al. 2014, 2015), immunomodulatory (Liberio et al. 2011), antibacterial (Liberio et al. 2011, Cunha et al. 2013, Campos et al. 2014, 2015), and antiproliferative (Cunha et al. 2013, Campos et al. 2014, 2015) activities. Their chemical compositions are extremely complex and their diversity depends on the flora visited and the season (Marcucci 1995, Bankova et al. 2000, Sforcin and Bankova 2011). Indeed, numerous potential bioactive metabolites have been reported previously in geopropolis, such as phenylpropanoids, flavonoids (Souza et al. 2013), gallotannins, ellagitannins (Dutra et al. 2014), benzophenones (Cunha et al. 2013, 2016), coumarins (Cunha et al. 2016) terpenes, and gallic acid (Bankova et al. 2000, Souza et al. 2013, Dutra et al. 2014). These findings have encouraged the exploration of $M$. mondury geopropolis as a potential source of novel bioactive compounds.

The biological activities and chemical compositions of geopropolis have been reported for many different stingless bee species (Liberio et al. 2011, Franchin et al. 2013, Cunha et al. 2013, Campos et al. 2014, 2015). However, there have been no previous pharmacological and chemical analyses of geopropolis from M. mondury. Therefore, we performed the first study of the in vitro antioxidant, antibacterial, and antiproliferative activities of geopropolis from M. mondury, as well as determining the chemical profile of its ethanolic extract and fractions. This study obtained reliable information, which may add value to this natural product.

\section{MATERIALS AND METHODS}

\section{GEOPROPOLIS SAMPLE AND FRACTIONATION}

Fresh samples of M. mondury geopropolis were collected in Nova Ibiá city, Bahia state, Brazil (1348'36' ' S, 39³7'32' ' W) during August 2015. The geopropolis $(100 \mathrm{~g})$ was extracted three times with absolute ethanol for $72 \mathrm{~h}$ and filtered to obtain the ethanolic extract of geopropolis (EEGP $=10 \mathrm{~g}$ ). EEGP was fractionated via liquid-liquid partitioning with hexane, ethyl acetate, and butanol solvents in order of increasing polarity to obtain hexane $(\mathrm{HFGP}=0.5 \mathrm{~g})$, ethyl acetate $(\mathrm{EAFGP}=$ $1.6 \mathrm{~g}$ ) and butanol fractions of geopropolis (BFGP $0.5 \mathrm{~g})$.

\section{TOTAL PHENOLIC CONTENTS}

The total phenolic contents of the extract and fractions was determined according to the FolinCiocalteu procedure (Slinkard and Singleton 1977, Piccinelli et al. 2004). Briefly, the samples at $1 \mathrm{mg} /$ $\mathrm{mL}(125 \mu \mathrm{L})$ was mixed with $125 \mu \mathrm{L}$ of FolinCiocalteau's reagent and $1 \mathrm{~mL}$ of distilled water. After $3 \mathrm{~min}, 125 \mu \mathrm{L}$ of saturated sodium carbonate solution was added and the mixture was incubated 
for $30 \mathrm{~min}$ at $37^{\circ} \mathrm{C}$ before measuring the absorbance at $765 \mathrm{~nm}$. A calibration curve was obtained with gallic acid $(0.5,5,10,15$ and $25 \mu \mathrm{g})$ and the results were expressed as $\mu \mathrm{g}$ gallic acid equivalent (GAE) per mg of sample.

\section{DETERMINATION OF ANTIOXIDANT ACTIVITIES}

The antioxidant activities of geopropolis samples were evaluated using three well-known methods: 'DPPH (2,2-diphenyl-1-picrylhydrazyl) free radical scavenging (Piccinelli et al. 2004), ABTS $^{\bullet+}$ (2,2'-azino-bis(3-ethylbenzothiazoline-6sulphonic acid cation radical) decolorization (Re et al. 1999), and $\beta$-carotene-linoleic acid cooxidation (Miller 1971, with minor modifications) assays.

In the DPPH assay, the samples (0-100 $\mu \mathrm{g} /$ $\mathrm{mL}$ ) were incubated to $2 \mathrm{~mL}$ of an ethanolic solution of ${ }^{\circ} \mathrm{DPPH}(70 \mu \mathrm{M})$. After $20 \mathrm{~min}$ at $25^{\circ} \mathrm{C}$, the absorbance was measured at $517 \mathrm{~nm}$. In the $\mathrm{ABTS}^{\bullet+}$ assay, we first prepared ABTS radical cation by reacting ABTS salt $(7 \mathrm{mM})$ concentration with potassium persulfate $(2.45 \mathrm{mM})$ and allowing the mixture to stand in the dark at room temperature for $16 \mathrm{~h}$ before use. The stock $\mathrm{ABTS}^{\bullet+}$ solution was diluted with ethanol (absorbance of 0.7 at $734 \mathrm{~nm})$ and incubated to samples $(0-100 \mu \mathrm{g} / \mathrm{mL})$ in a final volume of $2 \mathrm{~mL}$. The absorbance was measured at $734 \mathrm{~nm}$ after $7 \mathrm{~min}$ of incubation. In both experiments, the values were expressed as the concentration of sample necessary to reduce $50 \%$ of the free radicals $\left(\mathrm{IC}_{50}\right)$.

In the $\beta$-carotene-linoleic acid cooxidation assay, a stock solution of $\beta$-carotene/linoleic acid was initially prepared by dissolving $2 \mathrm{mg}$ of $\beta$-carotene in $100 \mu \mathrm{L}$ of chloroform. Ten microliters of $\beta$-carotene solution were mixed to 40 $\mathrm{mg}$ of linoleic acid and $530 \mu \mathrm{L}$ of Tween 40 . The chloroform was rotaevaporated and aerated distilled water was added to the mixture until an initial absorbance of 0.65 at $470 \mathrm{~nm}$. Two milliliters of $\beta$-carotene/linoleic acid emulsion were mixed with samples at $74 \mu \mathrm{g} / \mathrm{mL}$. The reactions were incubated at $50^{\circ} \mathrm{C}$ for $2 \mathrm{~h}$ before taking another absorbance reading. The data were expressed as the percentage inhibition of $\beta$-carotene bleaching by geopropolis extract or fraction (\% IO).

In all assays gallic acid and trolox were used as positive controls.

\section{DETERMINATION OF ANTIBACTERIAL ACTIVITY}

\section{Bacterial strains}

The bacterial strains used in this study were Staphylococcus aureus ATCC 29213, Pseudomonas aeruginosa ATCC 27853 and methicillin-resistant Staphylococcus aureus (CA-MRSA). The CAMRSA strain was cultured at the Microbiology Laboratory in the Multidisciplinary Institute of Health, Federal of University of Bahia. This strain was isolated from raw human milk (LC2). Phenotypic and genotypic tests, identification of the nuc gene (Brakstad et al. 1992), detection of the mecA gene (Perez-Hoth et al. 2001), and chromosomal cassette typing mec (ssmec) (Boye et al. 2007) were conducted to identify the strains. The isolated LC2 was positive for the nuc gene and $m e c A$ as well as ssmec, and thus typed as IV, which characterized it as a CA-MRSA strain.

\section{Susceptibility testing}

The antibacterial activities of EEAGP and other fractions were examined by determining the minimum inhibitory concentration (MIC) and minimum bactericidal concentration (MBC) according to the Institute of Clinical and Laboratory Standards (CLSI 2006, Cunha et al. 2013). To determine the MIC, $5 \times 10^{5} \mathrm{CFU} / \mathrm{mL}$ diluted in brain heart infusion medium (Difco) were incubated with EEGP and fractions $(1-1000 \mu \mathrm{g} / \mathrm{mL})$ in 96 -well microplates for $24 \mathrm{~h}$ at $37^{\circ} \mathrm{C}$. The vehicle control was ethanol (final ethanol concentration $=5 \%$, $\mathrm{v} / \mathrm{v})$. MIC was defined as the lowest concentration 
of EEGP or fraction that allowed no visible growth after incubation with $0.01 \%$ resazurin dye (SigmaAldrich) for $60 \mathrm{~min}$ at room temperature. MBC was determined by sub-culturing $10 \mu \mathrm{L}$ of each incubated well that had a concentration higher than the MIC on Müller-Hinton agar. The MBC was then treated as the lowest concentration of each sample with no visible colony growth on agar plates. Tetracycline and ceftriaxone were used as positive controls for Gram-positive and -negative bacteria, respectively.

\section{ANTIPROLIFERATIVE ASSAY}

\section{Cells}

Antiproliferative effects were determined in tumor cell lines: B16-F10 (mouse melanoma), HepG2 (human hepatocellular carcinoma), K562 (human chronic myelocytic leukemia), and HL60 (human promyelocytic leukemia). All of the cell lines were kindly provided by Hospital A.C. Camargo (São Paulo, SP, Brazil) and maintained in Roswell Park Memorial Institute-1640 (RPMI1640; Gibco) medium supplemented with $10 \%$ fetal bovine serum (Cultilab), $2 \mathrm{mM}$ L-glutamine (Vetec Química Fina), and $50 \mu \mathrm{g} / \mathrm{mL}$ gentamycin (Novafarma). All cell lines were cultured in cell culture flasks at $37^{\circ} \mathrm{C}$ in $5 \% \mathrm{CO}_{2}$ and subcultured every 3-4 days to maintain exponential growth (Rodrigues et al. 2015)

Peripheral blood mononuclear cells (PBMCs) were isolated from healthy, non-smoker donors using a Ficoll-Paque density gradient (GE Healthcare). PBMCs were washed and resuspended at a concentration of $0.3 \times 10^{6}$ cells $/ \mathrm{mL}$ in RPMI 1640 medium supplemented with $20 \%$ fetal bovine serum, $2 \mathrm{mM}$ glutamine, and $50 \mu \mathrm{g} / \mathrm{mL}$ gentamycin at $37^{\circ} \mathrm{C}$ with $5 \% \mathrm{CO}_{2}$. Next, the cells were incubated with a T-lymphocyte-specific mitogen, concanavalin A (10 $\mu \mathrm{g} / \mathrm{mL}$, Sigma Chemical Co.), for $24 \mathrm{~h}$ before the experiments to obtain a culture of human lymphoblasts (Berthold 1981, Brown and Lawce 1997). In all experiments, cell viability was determined using the Trypan blue assay ( $>90 \%)$.

The Research Ethics Committee of the Oswaldo Cruz Foundation (Salvador, Bahia, Brazil) approved the experimental protocol (\#031019/2013). All blood donors signed a written informed consent form to participate in the study.

\section{In vitro antiproliferative activity assay}

Cell viability was quantified using the Alamar Blue assay, as described previously by Ahmed et al. (1994) with minor modifications (Rodrigues et al. 2015). Non-tumor and tumor cells were placed in 96-well plates $\left(7 \times 10^{4}\right.$ cells $/ \mathrm{mL}$ for adherent cells or $3 \times 10^{5}$ cells $/ \mathrm{mL}$ for suspended cells in $100 \mu \mathrm{L}$ of medium) and incubated with EEGP or its fractions $(0.39-50 \mu \mathrm{g} / \mathrm{mL})$ for $72 \mathrm{~h}$ at $37^{\circ} \mathrm{C}$ under a $\mathrm{CO}_{2}(5 \%)$ atmosphere. Cell viability was quantified based on the ability of living cells to reduce Alamar Blue dye $(52 \mu \mathrm{g} / \mathrm{mL}$; Sigma Aldrich) to a red resorufin product where the absorbance was measured at 570 and $600 \mathrm{~nm}$ (DTX-880, Beckman Coulter) after 2h at $37^{\circ} \mathrm{C}$ under $\mathrm{CO}_{2}(5 \%)$ atmosphere. Doxorubicin (purity $\geq 95 \%$, doxorubicin hydrochloride, Laboratory IMA) was used as the positive control $(0.08-5 \mu \mathrm{g} / \mathrm{mL})$.

\section{CHEMICAL ANALYSIS}

Chromatographic analyses of samples were performed using a UPLC Acquity chromatograph coupled with a TQD Acquity mass spectrometer (Micromass-Waters), with an electrospray ionization (ESI) source in the negative mode. The column was a C18 BEH Waters Acquity $(2.1 \mathrm{~mm} x$ $50 \mathrm{~mm} \times 1.7 \mu \mathrm{m}$ particle size). The mobile phases were $0.1 \%$ ammonium hydroxide (phase A) and methanol (phase B). The flow rate was $0.2 \mathrm{~mL} /$ min with a linear gradient starting at $75 \% \mathrm{~B}$ and increasing to up $100 \%$ methanol in $9 \mathrm{~min}$, before holding until $10 \mathrm{~min}$, and then returning to the initial 
conditions, followed by column re-equilibration. The ESI conditions were: capillary $=3.00 \mathrm{kV}$, cone $=30 \mathrm{~V}$, source temperature $=150^{\circ} \mathrm{C}$, desolvation temperature $=350^{\circ} \mathrm{C}$, and collision energy $=30 \mathrm{~V}$, with data acquisition between $m / z 100$ and 1000 .

The (ESI(-)-MS) fingerprints were obtained by direct injection in duplicate using $0.01 \mathrm{~mL}$ of EEGP and the fractions $(1 \mathrm{mg} / \mathrm{mL})$ by flow insertion with a solvent mixture comprising methanol:water (90:10 $\mathrm{v} / \mathrm{v}$ ) at flow rate of $0.1 \mathrm{~mL} / \mathrm{min}$. The components of geopropolis samples were putatively identified by comparing their $m / z$ values and fragmentation patterns with previous reports.

\section{STATISTICAL ANALYSIS}

Data were expressed as the mean \pm standard deviation or $\mathrm{IC}_{50}$ values based on three independent experiments. Significant differences $(p<0.05)$ were detected by one-way ANOVA with Tukey's post-test using GraphPad 4.00.

\section{RESULTS AND DISCUSSION}

The chemical composition of propolis is very complex and closely related to its biological activity (Bankova et al. 2000, Sforcin and Bankova 2011, Cunha et al. 2016). Phenolic compounds, terpenes, and aromatic acids are considered the main bioactive constituents of propolis (Bankova et al. 2000, Souza et al. 2013, Dutra et al. 2014). The total phenolic compounds and antioxidant activities of geopropolis samples produced by $M$. mondury are shown in Table I. BFGP contained the highest amount of phenolic (303.1 $\pm 0.1 \mu \mathrm{g} \mathrm{GAE} /$ $\mathrm{mg}$ ), which differed significantly from that in the other fractions $(p<0.05)$. HFGP contained a low concentration of phenolics (GAE $40.1 \pm 0.4 \mu \mathrm{g} / \mathrm{mg}$ ), as expected. In our study, the amount of reducing compounds was much higher than that found by Souza et al. (2013) in M. subnitida geopropolis from Paraiba state, Brazil (ranging from $25.6 \pm 0.5$ to $115.8 \pm 0.8 \mu \mathrm{g} \mathrm{GAE} / \mathrm{mg}$ ). This suggests that the bee species and/or its habitat influence the chemical composition of geopropolis (Campos et al. 2015).

Three different methods were employed to determine the antioxidant properties of the geopropolis: scavenging of $\mathrm{DPPH}^{\bullet}$ and $\mathrm{ABTS}^{\bullet+}$ radicals, and inhibition of $\beta$-carotene bleaching. All samples exhibited some radical scavenging activity against $\mathrm{DPPH}^{\bullet}$ and $\mathrm{ABTS}^{\bullet+}$ (Table I). BFGP was more effective fraction at reducing $\mathrm{DPPH}$ and ABTS $^{\circ+}\left(\mathrm{IC}_{50} \sim 2.2\right.$ and $0.9 \mu \mathrm{g} / \mathrm{mL}$, respectively). BFGP $(74 \mu \mathrm{g} / \mathrm{mL})$ inhibited $\beta$-carotene bleaching at around $78.6 \%$, which was similar to that with the same concentration of trolox standard. Unexpectedly, the hexane fraction had weak activity in the $\beta$-carotene/linoleic acid bleaching assay. Nevertheless, the antioxidant profile of $M$. mondury geopropolis was higher compared with that of M. subnitida geopropolis, which is known as Jandaíra in northeastern Brazil (Souza et al. 2013). Previously, it has been suggested that reducing compounds such as phenolics are responsible for the antioxidant activity of geopropolis (Souza et al. 2013, 2014, Campos et al. 2014, Dutra et al. 2014), which may explain why the BFGP had the highest antioxidant activity in all the assays.

Infectious diseases are important causes of morbidity and mortality among humans, especially in developing and poor countries. S. aureus and $P$. aeruginosa are particularly important because they are often associated with nosocomial infections, and they have increased resistance to many clinically available antibiotics, thereby stimulating the search for alternative treatments (Cinegaglia et al. 2013, Sampaio et al. 2013). Geopropolis has also been proposed as an alternative for prevention and/or treatment of infectious diseases because it has broad antimicrobial activities. In fact, several types of geopropolis have antibacterial properties (Liberio et al. 2011, Cunha et al. 2013, Campos et al. 2014, 2015).

According to this study, M. mondury geopropolis had antibacterial activities against 
TABLE I

Total phenolics and antioxidant activities of the Melipona mondury geopropolis extract and fractions.

\begin{tabular}{|c|c|c|c|c|}
\hline Sample & Total Phenolics $\mu \mathrm{g}$ GAE/mg & ${ }^{\cdot} \mathrm{DPPH} \mathrm{IC}_{50}(\mu \mathrm{g} / \mathrm{mL})$ & $\operatorname{ABTS}^{\bullet+} \operatorname{IC}_{50}(\mu \mathrm{g} / \mathrm{mL})$ & $\begin{array}{c}\beta \text {-carotene-linoleic } \\
\text { acid cooxidation (\% IO) }\end{array}$ \\
\hline EEGP & $144.4 \pm 0.01^{a}$ & $6.91 \pm 017^{a}$ & $5.96 \pm 0.08^{a}$ & $27.99 \pm 0.2^{a}$ \\
\hline HFGP & $40.12 \pm 0.4^{b}$ & $20.22 \pm 0.2^{b}$ & $20.51 \pm 0.15^{b}$ & $4.7 \pm 0.001^{b}$ \\
\hline EAFGP & $140.9 \pm 0.28^{a}$ & $6.58 \pm 0.04^{c}$ & $5.5 \pm 0.028^{c}$ & $26.45 \pm 0.4^{a}$ \\
\hline BFGP & $303.1 \pm 0.14^{c}$ & $2.23 \pm 0,05^{d}$ & $0.87 \pm 0.003^{d}$ & $78.57 \pm 0.3^{c}$ \\
\hline Trolox & - & $1.54 \pm 0.01^{e}$ & $1.20 \pm 0.035^{e}$ & $83.69 \pm 0.7^{d}$ \\
\hline Gallic acid & - & $1.45 \pm 0.01^{e}$ & $1.08 \pm 0.04^{d, e}$ & $54.7 \pm 0.4^{e}$ \\
\hline
\end{tabular}

EEGP $=$ ethanolic extract of geopropolis, $\mathrm{HFGP}=$ hexane fraction of geopropolis, EAFGP = ethyl acetate fraction of geopropolis, $\mathrm{BFGP}=$ butanol fraction of geopropolis. For the $\beta$-carotene-linoleic acid cooxidation method, samples were incubated at $74 \mu \mathrm{g} /$ $\mathrm{mL}$. Values represent the mean \pm standard deviation based on triplicate measurements. The same superscript letters in the same column indicate that the values are not different, whereas different superscript letters denote that the values are significantly different (Tukey's test, $p<0.05$ ).

Gram-positive and -negative bacteria (Table II). EEGP exhibited bactericidal activity against $P$. aeruginosa, a Gram-negative bacillus (MIC = $\mathrm{MBC}=250 \mu \mathrm{g} / \mathrm{mL})$. BFGP inhibited the growth of $S$. aureus, CA-MRSA, and $P$. aeruginosa at concentrations of $5-10,250$, and $500 \mu \mathrm{g} / \mathrm{mL}$, respectively. The $\mathrm{MBC}$ values showed that BFGP had bactericidal activities at concentrations of 25 and $1000 \mu \mathrm{g} / \mathrm{mL}$ against $S$. aureus and $P$. aeruginosa, respectively. The MIC and MBC values for BFGP against all bacterial strains were comparable to those of standard antibiotics, such as ceftriaxone ( $\mathrm{MIC}=3 \mu \mathrm{g} / \mathrm{mL}$ and $\mathrm{MBC}=10 \mu \mathrm{g} /$ $\mathrm{mL})$ and tetracycline $(\mathrm{MIC}=\mathrm{MBC}=3 \mu \mathrm{g} / \mathrm{mL})$, considering that BFGP is a complex sample. The MIC values of EAFGP against $S$. aureus, CAMRSA, and $P$. aeruginosa were 25, 500, and 250 $\mu \mathrm{g} / \mathrm{mL}$, respectively. The EAFGP had a bactericidal effect only on $S$. aureus at $1000 \mu \mathrm{g} / \mathrm{mL}$. EEGP and its fractions had no bactericidal effects on CAMRSA at the test concentrations (MIC $>1000$ $\mu \mathrm{g} / \mathrm{mL})$. These results demonstrate that all of the samples were bactericidal agents $(\mathrm{MIC} / \mathrm{MBC} \leq 4)$, except for EAFGP $(\mathrm{MBC} / \mathrm{MIC}=40)$, according to French (2006).
Previously, Campos et al. (2014) reported MIC and MBC values $>1000 \mu \mathrm{g} / \mathrm{mL}$ against $S$. aureus and $E$. coli for an ethanolic extract of $M$. orbignyi geopropolis collected in Mato Grosso do Sul state, Brazil. Velikova et al. (2000) also demonstrated that M. quadrifasciata geopropolis had antibacterial activities against $S$. aureus and $E$. coli. Campos et al. (2015) found that the ethanolic extract of Tetragonisca fiebrigi geopropolis (known as Jatai) had antibacterial effects on two strains of $S$. aureus (MIC $=0.55-0.65 \mathrm{mg} / \mathrm{mL}$ and $\mathrm{MBC}>1000 \mu \mathrm{g} / \mathrm{mL}$ ) and $P$. aeruginosa (MIC and $\mathrm{MBC}>1000 \mu \mathrm{g} / \mathrm{mL}$ ). In these studies, it was suggested that prenylated benzophenones (Cunha et al. 2013), diterpene kaurenoic acid (Velikova et al. 2000), cinnamic acid (Campos et al. 2015), and $p$-coumaric acid (Campos et al. 2015) in the different types of geopropolis were responsible for their antibacterial properties.

The ethanolic extract of geopropolis from $M$. scutellaris (known as Uruçu verdadeira) and its hexane fraction had strong antibacterial activities against $S$. aureus and $S$. aureus MRSA strains (MIC $=6.25-12.5 \mu \mathrm{g} / \mathrm{mL}$ and $\mathrm{MBC}=25-50 \mu \mathrm{g} / \mathrm{mL})$, but no activity against $P$. aeruginosa. By contrast, our 
BFGP had similar MIC and MBC values against $S$. aureus to the hexane fraction of $M$. scutellaris geopropolis (Cunha et al. 2013). It should be noted that we determined all the MIC values only after incubating with resazurin for $60 \mathrm{~min}$ because shorter incubation periods overestimated the results (data not shown). Unfortunately, the incubation time employed by Cunha et al. (2013) was not stated.

Propolis has also been reported to have cytotoxic effects against several tumor cell lines (Cunha et al. 2013, 2016, Cinegaglia et al. 2013, Campos et al. 2015). Thus, we evaluated the in vitro antiproliferative potential of $M$. mondury geopropolis in four cell tumor lines: B16-F10, HepG2, HL-60, and K562 (Table III). EEGP had antiproliferative activities against tumor cells with $\mathrm{IC}_{50}$ values ranging from 33.48 to $48.67 \mu \mathrm{g} / \mathrm{mL}$ using HL-60 and HepG2. HFGP had $\mathrm{IC}_{50}$ values ranging from 24.24 to $46.62 \mu \mathrm{g} / \mathrm{mL}$ using HL-60 and $\mathrm{K} 562$. EAFGP had $\mathrm{IC}_{50}$ values ranging from 29.79 to $45.90 \mu \mathrm{g} / \mathrm{mL}$ using B16-F10 and HepG2. BFGP was not tested because it exhibited no antiproliferative activity at $50 \mu \mathrm{g} / \mathrm{mL}$ in preliminary screening using HepG2 and HL-60 cells. According

TABLE II

Minimum inhibitory concentration (mic) and minimum bactericidal concentration $(\mathrm{mbc})$ values for the geopropolis ethanolic extract and its fractions.

\begin{tabular}{ccccccccc}
\hline Bacterial strains & \multicolumn{2}{c}{ EEGP $^{a}$} & \multicolumn{2}{c}{ HFGP $^{a}$} & \multicolumn{2}{c}{ EAFGP $^{a}$} & \multicolumn{2}{c}{ BFGP $^{a}$} \\
\hline & MIC & MBC & MIC & MBC & MIC & MBC & MIC & MBC \\
\hline Staphylococcus aureus ATCC 29213 & 250 & 1000 & 500 & $b$ & 25 & 1000 & $5-10$ & 25 \\
Staphylococcus aureus (CA-MRSA) & $b$ & $b$ & $b$ & $b$ & 500 & $b$ & 250 & $b$ \\
Pseudomonas aeruginosa ATCC 27853 & 250 & 250 & 1000 & $b$ & 250 & $b$ & 500 & 1000 \\
\hline
\end{tabular}

$\mathrm{EEGP}=$ ethanolic extract of geopropolis, $\mathrm{HFGP}=$ hexane fraction of geopropolis, EAFGP = ethyl acetate fraction of geopropolis, $\mathrm{BFGP}=$ butanol fraction of geopropolis. ${ }^{\mathrm{a}}$ concentration at $\mu \mathrm{g} / \mathrm{mL}$. ${ }^{\mathrm{b}}$ values $>1000 \mu \mathrm{g} / \mathrm{mL}$.

TABLE III

In vitro antiproliferative activities of Melipona mondury geopropolis ethanolic extract and its fractions.

\begin{tabular}{cccccc}
\hline & \multicolumn{5}{c}{ IC $_{\mathbf{5 0}}$ values $(\boldsymbol{\mu g} / \mathbf{m L})$} \\
\cline { 2 - 5 } Samples & B16-F10 & HepG2 & HL-60 & K562 & $\begin{array}{c}\text { Human } \\
\text { lymphoblast }\end{array}$ \\
\hline \multirow{2}{*}{ EEGP } & 35.70 & 48.67 & 33.48 & 46.93 & $>50$ \\
& $32.60-39.11$ & $37.93-62.46$ & $30.48-36.78$ & $35.96-61.25$ & $>50$ \\
HFGP & 28.00 & 39.41 & 24.24 & 46.62 & 47.67 \\
& $25.54-30.71$ & $36.46-42,60$ & $21.54-27.27$ & $35.95-60.45$ & $41.40-54.89$ \\
EAFGP & 29.79 & 45.90 & 35.57 & 42.19 & 2.19 \\
& $26.74-33.19$ & $40.89-51.53$ & $31.71-39.89$ & $35.14-50.65$ & 0.29 \\
DOX & 0.20 & 0.19 & 0.18 & $0.23-0.37$ & $1.08-4.43$ \\
\hline
\end{tabular}

$\mathrm{IC}_{50}$ values in $\mu \mathrm{g} / \mathrm{mL}$ and their $95 \%$ confidence interval obtained by nonlinear regression based on three independent experiments performed in duplicate, which were measured based on the Alamar Blue assay after incubation for $72 \mathrm{~h}$. Doxorubicin (DOX) was used as the positive control. EEGP = ethanolic extract of geopropolis, HFGP = hexane fraction of geopropolis, EAFGP $=$ ethyl acetate fraction of geopropolis, BFGP was not tested because it exhibited no antiproliferative activity in preliminary screening. Tumor cells: B16-F10 (mouse melanoma), HepG2 (human hepatocellular carcinoma), HL-60 (human promyelocytic leukemia), and K562 (human chronic myelocytic leukemia). Non-tumor cell: human peripheral blood mononuclear cells triggered with concanavalin $\mathrm{A}=$ human lymphoblast. 
to Suffness and Pezzuto (1990), extracts with $\mathrm{IC}_{50}$ values $<30 \mu \mathrm{g} / \mathrm{mL}$ are promising cytotoxic agents for use against neoplastic cells. In addition, EEGP and HFGP had no cytotoxic effects on non-tumor cells (human lymphocyte T) whereas EAFGP had an $\mathrm{IC}_{50}$ value of $47.67 \mu \mathrm{g} / \mathrm{mL}$ in lymphoblast cells. Therefore, HFGP is a promising source for the isolation and identification of antiproliferative compounds.

To determine the chemical profile of $M$. mondury geopropolis, the EEGP and its fractions were analyzed by direct infusion negative ion mode electrospray ionization mass spectrometry (ESI()-MS). The most abundant anions $[\mathrm{M}-\mathrm{H}]^{-}$in all samples were at $m / z 169,475,569$, and 601 . We also observed other less intense ions $(\mathrm{m} / \mathrm{z} 301,373,401$, and 569) in the raw extract and fractions (Figure $1)$. We then performed chromatographic analysis using UHPLC-MS and obtained the UHPLC-MS/ MS spectra of selected peaks based on the main ions in the fingerprints (Table IV).

The ion at $m / z 169$ and its fragments (Figures $2 a$ and $b$ ) were characteristic of gallic acid based on comparisons with previous studies (Abdel-Hameed et al. 2013, Saldanha et al. 2013). In addition, this compound was previously identified in Myrcia bella, which is a source of resin for M. mondury (Z.S. Lopes et al., unpublished data).

The ion at $m / z 301$ and its fragments (Figures $2 \mathrm{c}$ and d) were compatible with $E / Z$ communic acid isomers, which were identified previously in some types of Brazilian propolis and Araucaria heterophylla resins (Marcucci et al. 2008). E/Z communic acid is a diterpene (Barrero et al. 2012) with several known pharmacological properties, including antimicrobial, antitumoral, antiinflammatory, and antioxidant activities (Velikova et al. 2000, Popova et al. 2009, Barrero et al. 2012, Campos et al. 2015).

Previous studies of propolis produced by native bees from different Brazilian regions found ions at $\mathrm{m} / \mathrm{z} 373$ (Figures 2e and $\mathrm{f}$ ) and 401 as diagnostic of terpenes with acid groups present in Schinus terebinthifolius resin (e.g., Sawaya et al. 2006, 2007, 2009). M. mondury geopropolis contained the same ions, which suggests that this bee also collects resin from S. terebinthifolius (e.g., Sawaya et al. 2007, 2009). This plant occurs naturally on the coastline of Brazil, in the remaining areas of the Atlantic Forest (Carvalher-Machado et al. 2008), which is an area inhabited by M. mondury (Melo 2003, Souza et al. 2012).

Finally, the ions at $\mathrm{m} / \mathrm{z} 601,475$, and 569 (Figure 3) could not be identified, although they were present in all the samples produced by $M$. mondury tested in this study.

UHPLC-MS has been used widely for analyzing propolis (Bankova et al. 2000, Sawaya et al. 2011, Novak et al. 2014, Wali et al. 2015, Ristivojević et al. 2015, Sagi et al. 2016), but it has limitations in terms of the identification of uncommon substances because there is no database for making comparisons among geopropolis samples. Therefore, the unambiguous characterization of the compounds corresponding to the ions at $m / z 601,475$, and 569 may be possible after their isolation and further analysis using other spectrometric methods (e.g., NMR), in addition to MS experiments.

In this study, for the first time, we demonstrated that the geopropolis produced by M. mondury has antioxidant, antibacterial, and antiproliferative properties, thereby indicating the therapeutic potential of this natural product for the prevention and/or treatment of inflammatory, oxidative, and infectious diseases as an unexplored source of new antiproliferative compounds. The chemical composition of geopropolis appears to be partially polar because its activities were concentrated in the butanol fraction. Therefore, M. mondury geopropolis is a promising source for identifying new molecules with therapeutic properties. 


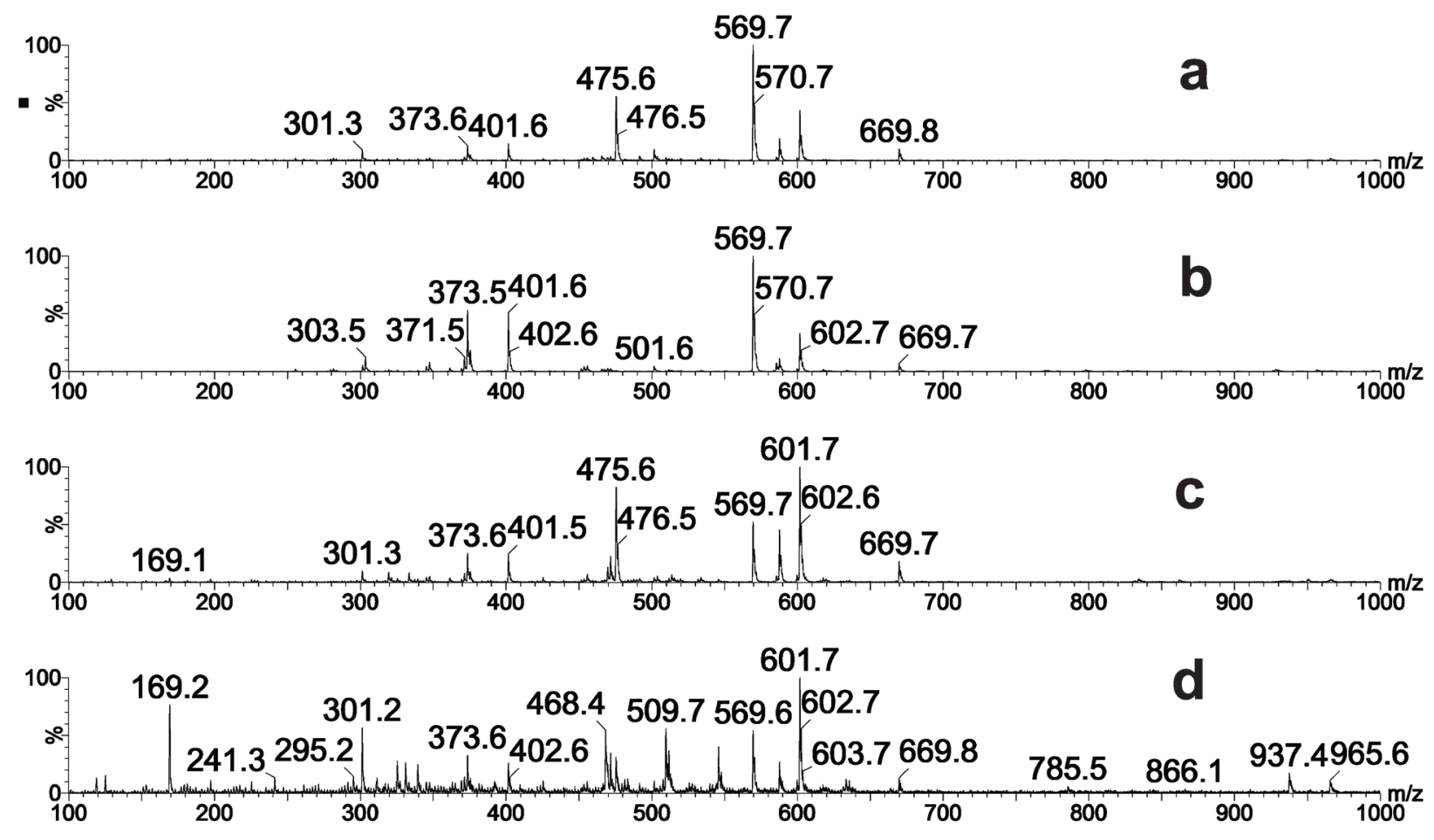

Figure 1 - ESI-MS fingerprints of M. mondury geopropolis extract and fractions determined in the negative ion mode. a) EEGP: ethanolic extract; b) HFGP: hexane fraction; c) EAFGP: ethyl acetate fraction; d) BFGP: butanol fraction.

TABLE IV

Retention times and $\mathrm{ms} / \mathrm{ms}$ fragments of main ions in $M$. mondury geopropolis determined by uhplc-esi(-)-ms/ms in the negative ion mode.

\begin{tabular}{ccc}
\hline Retention time (min) & {$[\mathbf{M}-\mathbf{H}]^{-}$} & Major fragments $(\boldsymbol{m} / \mathbf{z})$ \\
\hline 0.7 & 169 & 125,106 \\
3.9 & 301 & $220,205,109$ \\
2.7 & 373 & 329 \\
1.5 & 475 & $407,390,347,335$ \\
3.4 & 475 & 407,399 \\
4.8 & 475 & 399 \\
1.8 & 569 & 501 \\
1.7 & 601 & $550,491,109$ \\
\hline
\end{tabular}

\section{ACKNOWLEDGMENTS}

This study was supported by grants from Fundação de Amparo à Pesquisa do Estado da Bahia (FAPESB) (RED038/2014), Conselho Nacional de Desenvolvimento Científico e Tecnológico (CNPq) (462401/2014-6; 308575/2013-0), and Programa de Formação de Recursos Humanos - Petrobras
(PRH-PB 211). The authors are grateful to Prof. Dr. Lucas Miranda and Hellen Braga Martins MSc from the Multidisciplinary Institute of Health, Federal of University of Bahia, for generously providing the methicillin-resistant $S$. aureus (MRSA) strain. The authors also wish to thank Gleiza M. Costa for help with the microbiological assays. 

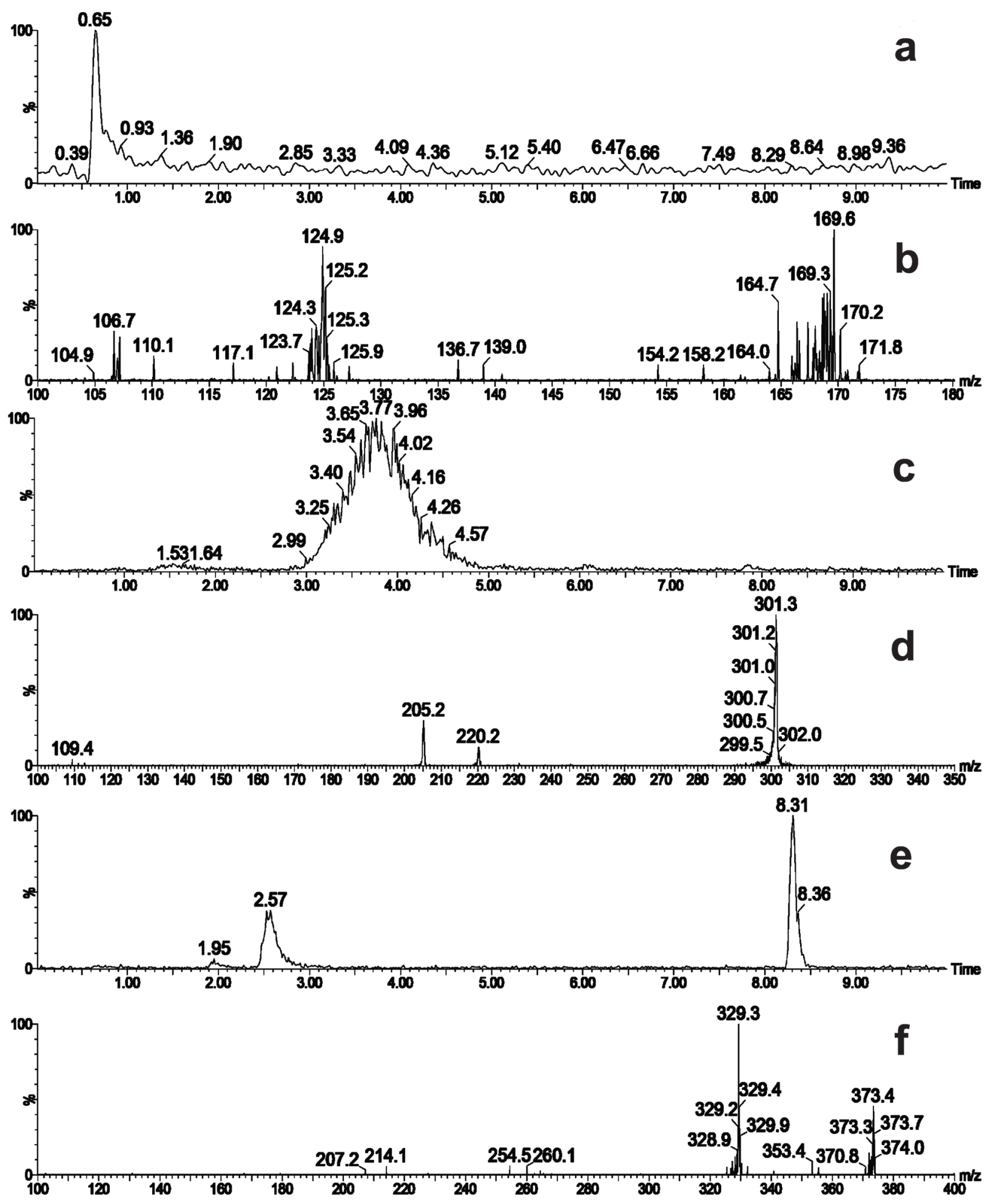

Figure 2 - Extracted ion UHPLC-MS chromatograms for (a) $m / z$ 169, (c) $m / z$ 301, and (e) $m / z$ 373. MS/MS fragments for ions (b) $m / z 169$, (d) $m / z 301$, and (f) $m / z 373$. 

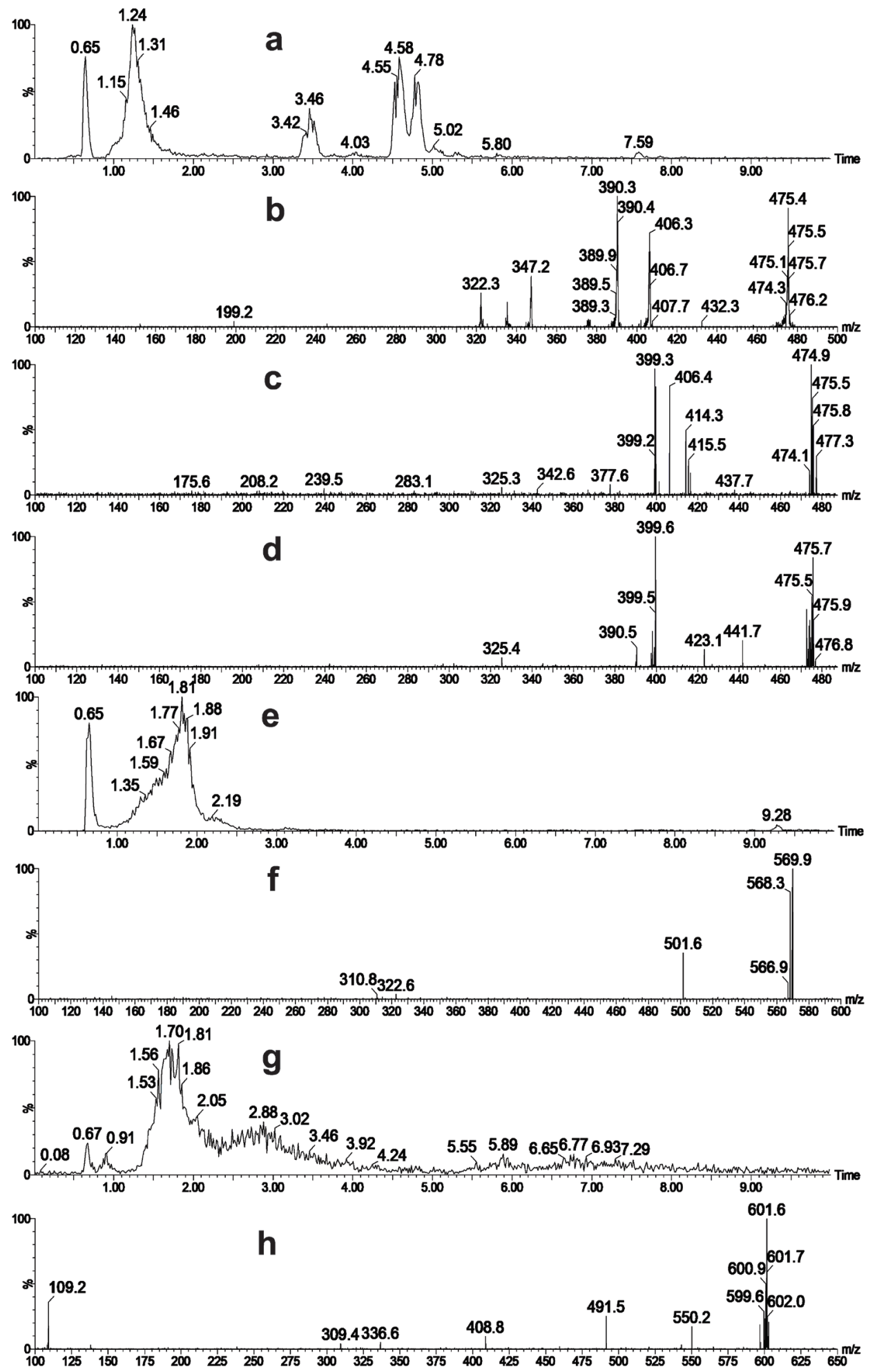

Figure 3 - Extracted ion UHPLC-MS chromatograms for (a) $m / z$ 475, (e) $\mathrm{m} / z$ 569, and (g) $\mathrm{m} / \mathrm{z} 601$. MS/MS fragments for ions (b) $\mathrm{m} / \mathrm{z} 475$, retention time $1.5 \mathrm{~min}$; (c) $\mathrm{m} / \mathrm{z} 475$, retention time $3.5 \mathrm{~min}$; (d) $\mathrm{m} / \mathrm{z} 475$, retention time $4.8 \mathrm{~min}$; (f) $\mathrm{m} / \mathrm{z} 569$; and (h) $\mathrm{m} / \mathrm{z} 601$. 


\section{REFERENCES}

ABDEL-HAMEED ES, BASAID SA AND SALMAN MS. 2013. Characterization of the phytochemical constituints of Taif Rose and its antioxidant and anticancer activities. Biomed Res Int 2013: 345465.

AHMED SA, GOGAL RM AND WALSH JE. 1994. A new rapid and simple non-radioactive assay to monitor and determine the proliferation of lymphocytes an alternative to $[3 \mathrm{H}]$ thymidine incorporation assay. J Immunol Meth 170: 211-224.

BANKOVA V, CASTRO SL AND MARCUCCI MC. 2000. Propolis: recent advances in chemistry and plant origin. Apidologie 31: 3-15.

BARRERO AF, HERRADOR MM, ARTEAGA P, ARTEAGA JF AND ARTEAGA AF. 2012. Communic acids: occurrence, properties and uses as chirons for the synthesis of bioactive compounds. Molecules 17: 1448-1467.

BERTHOLD F. 1981. Isolation of human monocytes by ficoll density gradient centrifugation. Blut 3: 367-371.

BRAKSTAD O, KJETILL A AND MAELND JA. 1992. Detection of Staphylococcus aureus by polymerase chain reaction amplification of the nuc Gene. J Clin Microbiol 30: 1654-1660.

BROWN MG AND LAWCE HJ. 1997. Peripheral blood cytogenetic methods. In: Barch MJ, Knutsen $\mathrm{T}$ and Spurbeck JL (Eds), The AGT Cytogenetics Laboratory Manual. Lippincott-Raven Publishers, Philadelphia, 3nd ed., p. 77-171.

BOYE K, BARTELS MD, ANDERSEN IS, MOLLER JA AND WESTH H. 2007. A new multiplex PCR for easy screening of methicillin-resistant Sthaphylococcus aureus SCC mec types I-V. Clin Microbiol Infect 13: 725-727.

CAMPOS JF, SANTOS UP, MACORINI LF, MELO AM, BALESTIERI JB, PAREDES-GAMERO EJ, CARDOSO CA, SOUZA KP AND SANTOS EL. 2014. Antimicrobial, antioxidant and cytotoxic activities of propolis from Melipona orbignyi (Hymenoptera, Apidae). Food Chem Toxicol 65: 374-380.

CAMPOS JF, SANTOS UP, ROCHA PS, DAMIÃO MJ, BALESTIERI JBP, CARDOSO CAL, PAREDESGAMERO EJ, ESTEVINHO LM, SOUZA KP AND SANTOS EL. 2015. Antimicrobial, antioxidant, antiinflammatory, and cytotoxic activities of propolis from the stingless bee Tetragonisca fiebrigi (Jataí). Evid Based Complement Alternat Med 2015: 296186.

CARVALHER-MACHADO SC, ROSAS EC, BRITO FA, HERINGE AP, OLIVEIRA RR, KAPLAN MA AND HENRIQUES MG. 2008. The anti-allergic activity of the acetate fraction of Schinus terebinthifolius leaves in $\operatorname{IgE}$ induced mice paw edema and pleurisy. Int Immunopharmacol 8: 1552-1560.
CINEGAGLIA NC, BERSANO PRO, ARAÚJO MJAM, BÚFALO MC AND SFORCIN JM. 2013. Anticancer effects of geopropolis produced by stingless bees on canine osteosarcoma cells in vitro. Evid Based Complement Alternat Med 2013: 737386.

CLSI - CLINICAL AND LABORATORY STANDARDS INSTITUTE. 2006. Methods for dilution antimicrobial susceptibility tests for bacteria that grow aerobically; approved standard. CLSI, Wayne, PA, USA, CLSI document M07-A7, 7.

CUNHA MG, FRANCHIN M, GALVÃO LCC, RUIZ ALTG, CARVALHO JE, IKEGAKI M, ALENCAR SM, KOO H AND ROSALEN PL. 2013. Antimicrobial and antiproliferative activities of stingless bee Melipona scutellaris geopropolis. BMC Complement Alternat Med 13: 23.

CUNHA MG, ROSALEN PL, FRANCHIN M, DE ALENCAR SM, IKEGAKI M, RANSOM T AND BEUTLER JA. 2016. Antiproliferative constituints of geopropolis from the bee Melipona scutellaris. Planta Med 82: 190-194.

DUTRA RP, ABREU BV, CUNHA MS, BATISTA MCA, TORRES LMB, NASCIMENTO FRF, RIBEIRO MNS AND GUERRA RNM. 2014. Phenolic acids, hydrolyzable tannins, and antioxidant activity of geopropolis from the stingless bee Melipona fasciculata Smith. J Agric Food Chem 62: 2549-2557.

FRANCHIN M, CUNHA MG, DENNY C, NAPIMOGA MH, CUNHA TM, KOO H, ALENCAR SM, IKEGAKI M AND ROSALEN PL. 2013. Bioactive fraction of geopropolis from Melipona scutellaris decreases neutrophils migration in the inflammatorlimy process: involvement of nitric oxide pathway. Evid Based Complement Alternat Med 2013: 907041.

FRENCH GL. 2006. Bactericidal agents in the tratament of MRSA infections- the potential role of daptomycin. J Amtimicrob Chemother 58: 1107-1117.

LIBERIO SA ET AL. 2011. Antimicrobial activity against oral pathogens and immunomodulatory effects and toxicity of geopropolis produced by the stingless bee Melipona fasciculata Smith. BMC Complement Alternat Med 11: 108.

MARCUCCI MC. 1995. Propolis: chemical composition, biological properties and therapeutic activity. Apidologie 26: 83-99.

MARCUCCI MC, SAWAYA ACHF, CUSTÓDIO AR, PAULINO NAND EBERLIN MN. 2008. Chapter 3: HPLC and ESI-MS typification: new approaches for natural therapy with Brazilian própolis. In Scientific Evidence of the Use of propolis in Ethnomedicine. Transworld Research Network, Kerala, India, p. 33-54.

MELO CAR. 2003. Notas sobre meliponíneos neotropicais (Hymenoptera, Apoidae). Com a descrição de três novas 
espécies. Apoidea Neotropical. Homenagem aos 90 anos de Jesus Santiago Moure 2003: 85-92.

MILLER HE. 1971. A simplified method for the evaluation of antioxidants. J Am Oil Chem Soc 48: 91.

NOVAK EM, SILVA MSC, MARCUCCI MC, SAWAYA ACHF, LÓPEZ BGC, FORTES MAHZ, GIORGI RR, MARUMO KT, RODRIGUES RF AND MARIA DA. 2014. Antitumoral actitivity of Brazilian red propolis enriched with xanthochymol and formononetin: an in vitro and in vivo study. J Funct Foods 11: 91-102.

PEREZ-HOTH E, CLAVERIE-MARTÍN F, VILLAR J AND MÉNDEZ-ÁLVAREZ S. 2001. Multiplex PCR for simultaneous identification of Sthaphylococcus aureus and detection of methicillin. J Clin Microbiol 39: 4037-4041.

PICCINELLI AL, DE SIMONE F, PASSI S AND RASTRELLI L. 2004. Phenolic constituents and antioxidant activity of Wendita calysina leaves (burrito), a folk Paraguayan tea. J Agric Food Chem 52: 5863-5868.

POPOVA MP, CHINOU IB, MAREKOV IN AND BANKOVA VS. 2009. Terpenes with antimicrobial activity from Cretan propolis. Phytochem 70: 1262-1271.

RE R, PELEGRINI N, PROTEGGENTE A, PANNALA A, YANG M AND RICE-EVANS C. 1999. Antioxidant activity applying an improved ABTS radical cation decolorization assay. Free Radic Biol Med 26: 1231-1237.

RISTIVOJEVIĆ P, TRIFKOVIĆ J, GAŠIĆ U, ANDRIĆ F, NEDIĆ N, TEŠIĆ Ž AND MILOJKOVIĆ-OPSENICA D. 2015. Ultrahigh-performance Liquid Chromatography and Mass Spectrometry (UHPLC-LTQ/Orbitrap/MS/ MS) study of phenolic profile of serbian poplar type propolis. Phytochem Anal 26: 127-136.

RODRIGUES AC, BOMFIM LM, NEVES SP, MENEZES LRA, DIAS RB, SOARES MB, PRATA APN, ROCHA CAG, COSTA EV AND BEZERRA DP. 2015. Antitumor properties of the essential oil from the leaves of Duguetia gardneriana. Planta Med 81: 798-803.

SAGI S, AVULA B, MASOODI MH , FAROOQ WALI A AND IA KHAN. 2016. Identification and quantification of chemical constituents from Indian bee propolis extracts using HPTLC and UHPLC-DAD-MS. Planta Med 83: 5.

SALDANHA LL, VILEGAS W AND DOKKEDAL AL. 2013. Characterization of Flavonoides and phenolic acids in Myrcia bella Cambess. Using a FIA-ESI-IT-MS and HPLC-PAD-ESI-IT-MS combined with NMR. Molecules 18: 8402-8416.

SAMPAIO CPL, DIAS IM, FARIA FM AND OLIVEIRA MVM. 2013. Principais bactérias causadoras de infecção hospitalar. Rev Dig Buenos Aires 10: 182.

SAWAYA ACHF, CALADO JCP, SANTOS LC, MARCUCCI MC, AKATSU IP, SOARES AEE, ABDELNUR PV, CUNHA IBS AND EBERLIN MN. 2009. Composition and antioxidant activity of propolis from three species of Scaptotrigona stingless bees. JAAS 1: 37-42.

SAWAYA ACHF, CUNHA IBS AND MARCUCCI MC. 2011. Analytical methods applied to diverse types of Brazilian propolis. Chem Cent J 5: 27.

SAWAYA ACHF, CUNHA IBS, MARCUCCI MC, AIDAR DS, SILVA ECA, CARVALHO CAL AND EBERLIN MN. 2007. Electrospray ionization mass spectrometry fingerprinting of propolis of native Brazilian stingless bees. Apidologie 38: 93-103.

SAWAYA ACHF, CUNHA IBS, MARCUCCI MC, RODRIGUES RFO AND EBERLIN MN. 2006. Brazilian propolis of Tetragonisca angustula and Apis mellifera. Apidologie 37: 398-407.

SFORCIN JM AND BANKOVA V. 2011. Propolis: is there a potential for the development of new drugs? J Ethnopharmacol 133: 253-260.

SLINKARD K AND SINGLETON VL. 1977. Total phenol analyses: automation and comparison with manual methods. Am J Enol Vitic 28: 49-55.

SOUZA HAC, VIANA MVC, ALVES RMO, PEREIRA DV AND WALDSCHMIDT AM. 2012. Distribution of Melipona mondury Smith1863 (Hymenoptera: Apidae, Meliponini) from state of Bahia. Semana Entomológica da Bahia. Magistra, Cruz das Almas 24: 99-104.

SOUZA SA, CAMARA CA, SILVA SEM AND SILVA TMS. 2013. Composition and antioxidant activity of geopropolis collected by Melipona subnitida (Jandaíra) bees. Evid Based Complement Alternat Med 2013: 801383.

SOUZA SA, DIAS TLMF, SILVA TMG, FALCÃO RA, ALEXANDRE-MOREIRA MS, SILVA EMS, CAMARA CA AND SILVA TMS. 2014. Chemical composition, antinociceptive and free radical-scavenging activities of geopropolis from Melipona subnitida Ducke (Hymenoptera: Apidae: Meliponini). Sociobiology 61: 560-565.

SUFFNESS M AND PEZZUTO JM. 1990. Assays related to cancer drug discovery. In: Hostettmann, Keditor. Methods in Plant Biochemistry: Assays for Bioactivity. Academic Press: London, p. 71-133.

VELIKOVA M, BANKOVAA V, TSVETKOVAB I, KUJUMGIEVB A AND MARCUCCIC MC. 2000. Antibacterial ent-kaurene from Brazilian propolis of native stingless bees. Phytotherapie 71: 693-696.

WALI AF, AVULA B, ALI Z, KHAN IA, MUSHTAQ A, REHMAN MU, AKBAR S AND MASOODI MH. 2015. Antioxidant, hepatoprotective potential and chemical profiling of propolis ethanolic extract from Kashmir Himalaya region using UHPLC-DAD-QToF-MS. Biomed Res Int 2015: 393462. 